Volume 7 Issue 1, March 2020

Nationally Accredited Journal,

Decree No. B/4130/E5/E5.2.1/2019

\title{
The Validity of Electronic Contracts in Software Applications
}

\section{Bambang Tri Bawono ${ }^{1}$}

Abstract. The development of information and communication technology resulted in the form of agreements turned into electrical forms, which are commonly referred to as electronic contracts. Discussion on electronic contracts refers to Article 46 paragraph (2) President Regulation No. 71 of 2019 on the Implementation of Electronic Systems and Transactions must also fulfill the legal conditions of the agreement. Based on this case, it is necessary to do a deeper study of the electronic contract, because it certainly has the potential to not fulfill the legal conditions of the agreement.

Method research used in this research is library research. While the approach in this study uses a normative juridical approach. The source of legal material in this study uses primary and secondary legal materials.

The results of this study state that the validity of electronic contracts in software applications can be canceled and null and void. Electronic contracts in software applications can be canceled because they do not meet the subjective requirements in terms of skills. This is because those who make electronic contracts through click warp have the potential to be immature, because they are under 18 years of age. Especially in the context of the use of smartphones or other devices related to the use of software applications, there are no clear rules regarding the minimum limits of users of such smartphones or devices. While the electronic contract has the potential to be null and void because the electronic contract is potential to conflict with the laws and regulations of Article 47 paragraph (1) President Regulation No. 71 of 2019 on the Implementation of Electronic Systems and Transactions. Electronic contracts in software applications are generally made using foreign languages, while Article 47 paragraph (1) requires that electronic contracts faced by Indonesian citizens must be made in Indonesian.

Keywords: Electronic Contracts; Click Warp Agreement; Terms of Legitimate Agreement.

\section{Introduction}

The law of contract or contract law in force in Indonesia at present is the law of agreement as contained in Book III of the Civil Code. The Civil Code originated from Burgerlijk Wetboek (BW) which came into force in the Netherlands in 1838. The existence of the Civil Code adopted in Indonesia was basically due to the principle of concordance, so that laws originating from the Netherlands had to be applied in the Dutch East Indies in 1848. since 1848 until now, then the Civil Code which also

\footnotetext{
${ }^{1}$ Permanent Lecturer at the Faculty of Law, Sultan Agung Islamic University (Unissula) Semarang E-mail: bambang@unissula.ac.id
} 
includes the treaty law has been around 172 years old. During this period, there were no significant changes to the principles, rules, principles, or regulations regarding the treaty law contained in the Civil Code. ${ }^{2}$ It's just that, in practice there are several forms of agreement that have changed because it is influenced by several things, including due to the development of information and communication technology.

Today, the development of information and communication technology causes the form of agreements to change into an electric form, which is commonly referred to as an electronic contract. The validity of electronic contracts is based on Article 18 of Act No. 19 of 2016 on Amendments to Act No. 11 of 2008 on Electronic Information and Transactions. As for the definition of an electronic contract according to the Law Dictionary and Jurisprudence is an agreement made through an electronic system. ${ }^{3}$ The use of electronic contracts is generally used by companies engaged in startup or software application service providers. In general, electronic contracts established between application users and application service providers are at the beginning of use, after installation via a smartphone or other device. The term used in this electronic contract is known as a click warp agreement. ${ }^{4}$ According to Wikipedia, a click warp agreement is a digital request that offers an opportunity for individuals to accept or reject digitally mediated policies. ${ }^{5}$ The form of a click warp agreement varies greatly, but in general this agreement requires the user to agree with clicking Ok, agreeing, agreeing, next, and so on. Implementation of agreements like this generally uses a standard clause, so that when there is a rejection by the user, it automatically also rejects the use of the application as a whole.

The existence of an electronic contract like this, of course, must also adhere to the legal terms of the agreement as explained in Article 46 paragraph (2) President Regulation No. 71 of 2019 on the Implementation of Electronic Systems and Transactions. ${ }^{6}$ Article 46 paragraph (2) states that electronic contracts are considered valid if; there is an agreement of the parties, carried out by competent legal subjects or authorized representatives in accordance with the provisions of the legislation, there are certain things, and the object of the transaction must not conflict with the laws and regulations, decency and public order. Based on that fact, it is very important to know whether a click warp agreement like this already fulfills the terms of an electronic contract or not. This is due to the fact that electronic contracts in software applications have the potential to violate skills requirements, because it must be recognized that until now there are no rules regarding the minimum limit for the use of smart phones or other devices. Further, the existence of electronic contracts like this also does not recognize territorial boundaries, so many electronic contracts do not use Indonesian, but instead use foreign languages. Referring to this fact, does the form of electronic

\footnotetext{
2Sukami, 2008, Cyber Law: Kontrak Elektronik dalam Bayang-Bayang Pelaku Usaha, Pustaka Sutra, Surabaya, p. 42

${ }^{3}$ H.M. Fauzan dan Baharudin Siagian, 2017, Kamus Hukum dan Yurisprudensi, Kencana, Depok, p. 428

${ }^{4}$ Edi Santoso, 2018, Pengaruh Era Globalisasi Terhadap Hukum Bisnis Di Indonesia, Kencana, Depok, p. 131.

${ }^{5}$ https://en.m.wikipedia.org/wiki/Clickwrap.

${ }^{6}$ Susanti Adi Nugroho, 2015, Penyelesaian Sengketa Arbitrase dan Penerapan Hukumnya, Cet. Ketiga, Kencana,Depok, p. 485.
} 
Volume 7 Issue 1, March 2020

Nationally Accredited Journal,

Decree No. B/4130/E5/E5.2.1/2019

contract that has the potential to violate proficiency requirements and is made in a foreign language that meets the legal requirements of the agreement?

\section{Research methods}

Method research used in this research is library research. Mestika Zed defines library research as library research that utilizes sources from the library to obtain research data, so library research limits its activities to library collections. ${ }^{7}$ While the approach used in this research is normative juridical. In Soerjono Soekanto's view, normative juridical research is a series of legal research conducted by examining library material or secondary data as a basic material to be investigated by conducting a search of regulations and literature relating to the problem under study. ${ }^{8}$

While the legal materials used in this study consisted of primary and secondary legal materials. Primary legal material consists of legislation, official records or treatises relating to this research. Whereas secondary legal materials are related to legal materials which provide explanations to primary legal materials, such as books, literature, articles, papers and other materials taken from legal experts.

\section{Results and Discussion}

\subsection{The Validity of Electronic Contracts in Potential Software Applications can be Canceled and Canceled by Law}

The validity of electronic contracts in the legal system in Indonesia has been recognized and regulated in Article 18 of Act No. 19 of 2016 on Amendments to Act No. 11 of 2008 on Electronic Information and Transactions. Article 18 paragraph (1) states that electronic transactions as outlined in the Electronic Contract are binding on the parties. The definition of an electronic contract according to Article 1 paragraph (17) states that an electronic contract is an agreement of the parties made through an electronic system. ${ }^{9}$ While an electronic system is a series of electronic devices and procedures that function to prepare, collect, process, analyze, store, display, announce, send and / or disseminate electronic information. ${ }^{10}$

In principle, electronic contracts are a form of new model agreements that exist in society due to the development of information and communication technology. That is why, agreements like this are included in the category of innominate agreements (not named) as regulated in Article 1319 of the Civil Code. ${ }^{11}$ Article 1319 of the Civil Code states that all agreements, whether they have a special name or are not known by a

\footnotetext{
${ }^{7}$ Mustika Zed, 2008, Metodologi Penelitian Kepustakaan, Yayasan Obor Indonesia, Jakarta, p. 1-2.

${ }^{8}$ Soerjono Soekanto dan Sri Mamudji, 2001, Penelitian Hukum Normatif (Suatu Tinjauan Singkat), Rajawali Pers, Jakarta, p. 13.

${ }^{9}$ Burhan Bungin, 2018, Komunikasi Politik Pencitraan; The Social Construction of Public Administration (Scopa), Prenada Media Group, Jakarta, p. 213.

${ }^{10}$ BIP Editorial Team, 2017, UU No. 19 Tahun 2016 tentang Perubahan Atas UU No. 11 Tahun 2008 tentang Informasi dan Transaksi Elektronik, Penerbit Buana Ilmu Populer, Jakarta, p. 33.

${ }^{11}$ Suwardi, 2012, Hukum Dagang Suatu Pengantar, Penerbit Deepublish, Yogyakarta, p. 180.
} 
certain name, are subject to the general rules contained in this chapter and the previous chapter. ${ }^{12}$ Based on these provisions, the electronic contract must also fulfill the legal conditions of the agreement. Provisions regarding the legal terms of electronic contracts are contained in Article 46 paragraph (2) President Regulation No. 71 of 2019 on the Implementation of Electronic Systems and Transactions. Provisions regarding the legal conditions of agreement in this Government Regulation are also similar to the legal conditions of agreement as contained in Article 1320 of the Civil Code. Content of Article 46 paragraph (2) President Regulation No. 71 of 2019 on the Implementation of Electronic Systems and Transaction state that electronic contracts are considered valid if: there is agreement between the parties; conducted by capable legal subjects or authorized representatives in accordance with statutory provisions; there are certain things; the object of the transaction must not be in conflict with the laws and regulations, decency and public order.

First, there is an agreement of the parties. The terms of the agreement give the meaning that both parties in an agreement must have a free will to bind themselves, and that will must be stated explicitly or secretly in making an agreement. ${ }^{13}$ The agreement is a statement of will consisting of two elements, namely offer and acceptance. The offer element is interpreted as a statement of intent containing the proposal to enter into an agreement. While the element of acceptance is a statement of agreement from other parties offered. ${ }^{14}$ Offer elements contained in software applications are generally found at the beginning of use, after installation by potential users. The offer elements in this software application mostly use standard clauses, so potential users do not have the right to change the agreement, but can only approve or reject it.

As for the element of acceptance, generally carried out by clicking on the icon that has been prepared by the application service provider. This type of agreement is commonly referred to as a click warp agreement. Click warp agreement is a contract for the purchase of goods or use of goods or services offered through online media. ${ }^{15}$ In this case, potential application users must agree to some of the requirements that have been outlined in the application window by clicking the I accept, I agree, Ok, agree and so on. Meanwhile, when potential users do not agree to the agreement, then he can reject it by clicking the cancel icon or other words that are similar to it. ${ }^{16}$

Referring to the contract agreement through click warp agreement, then it has been proven that there has been an agreement between the parties. Implementation of the agreement by using a click warp agreement has also been done. Even some cases abroad also mentioned that there is almost no court that rejects the agreement in this way. Furthermore, when referring to jurisprudence in America as an additional source

\footnotetext{
${ }^{12}$ Rustam Magun Pikahulan, 2019, Hukum Perikatan, IAIN Parepare Nusantara Press, Pare-Pare, p. 65.

${ }^{13}$ R. Soeroso, 2010, Perjanjian di Bawah Tangan; Pedoman Praktis Pembuatan dan Aplikasi Hukum, Penerbit Sinar Grafika, Jakarta, p. 12.

${ }^{14}$ Agus Yudho Hernoko, 2014, Hukum Perjanjian; Asas Proporsionalitas dalam Kontrak Komersial, Cet. Keempat, Kencana, Depok, p. 162.

${ }^{15}$ Edi Santoso, Pengaruh Era Globalisasi Terhadap Hukum Bisnis Di Indonesia, p. 131.

${ }^{16}$ Edy Santoso, 2015, Tinjauan Hukum Atas Click Warp Agreement Pada Kontrak Baku Elektronik Terkait Transaksi Elektronik, Jurnal Living Law, Vol. 7, No. 1, p. 7.
} 
of law, then the contract agreement by clicking I agree or I accept is legal and valid as usual. ${ }^{17}$ While the legal terms of agreement in the United States are: there are offers and acceptance, meeting of minds, consideration (achievements), and competent legal parties and legal subject matter (legitimate subject matter). ${ }^{18}$

Second, it is carried out by capable legal subjects or authorized representatives in accordance with statutory provisions. The skill requirement is one of the most important conditions in making an agreement, because each agreement will result in legal consequences from what it has promised. ${ }^{19}$ Discussion on legal subjects capable and authorized to carry out legal actions is regulated in Article 1330 of the Civil Code. Article 1330 of the Civil Code states that they are incapable of entering into an agreement: persons who are not yet mature, those who are placed in custody, and women in matters stipulated by law, and in general everyone to whom the law has prohibited making certain agreements. ${ }^{20}$

The size of a person can be said to be an adult in general is measured by the standard age of adulthood or sufficient age (beekwamheid-meederjarig). It's just that, in terms of measuring the standards of adulthood it turns out to also cause differences of opinion, bearing in mind that some argue that the standard age of maturity is 21 years based on Article $1330 \mathrm{BW}$ jo. $330 \mathrm{BW} .{ }^{21}$ While there are also those who argue that the standard age for maturity is 18 years based on Article 1 of Act No. 35 of 2014 on Child Protection which states that "a child is someone who is not yet 18 (eighteen) years old, including children who are still in the womb." In addition, other provisions which state that the standard of maturity when a person is 18 years old is also emphasized in Act No. 3 of 1997 on Juvenile Courts (Vide article 5 Jo.61), Act No. 30 of 2004 on Notary Position Regulations (Vide Article 39 jo. 30), and Act No. 12 of 2006 on Citizenship of the Republic of Indonesia (Vide Article 5, jis, 6, 9, 21, 22, and 41). Furthermore, even the Netherlands which was used as a reference source of law regarding the standard of maturity, which initially stated that the standard for adult age was 21 years. ${ }^{22}$

As for those who are under control are adults, but in a state of madness, dark eyes and wasters as stated in Article 1330 of the Civil Code in conjunction with Article 433 of the Civil Code, so that people like this legal actions are represented by their parents or her guardian. ${ }^{23}$ While the provisions on women in matters stipulated by law are abolished referring to the Supreme Court Circular No. 3 of 1963 on the Idea Regarding BW Not as Law and Article 31 of Act No. 1 of 1974 in conjunction with Act No. 16 of 2019 on marriage.

\footnotetext{
${ }^{17}$ Edi Santoso, Pengaruh Era Globalisasi Terhadap Hukum Bisnis Di Indonesia, p. 133.

18 https://hukumadmissible.wordpress.com/tag/ agreement /

${ }^{19}$ Marilang, 2017, Hukum Perikatan; Perikatan yang Lahir dari Perjanjian, Indonesia Prime, Makassar, p. 271-272.

${ }^{20}$ R. Subekti dan R. Tjitrosudibio, 2006, Kitab Undang-Undang Hukum Perdata (Burgerlijk Wetboek), Ed.37, Pradnya Paramita, Jakarta, p. 341.

${ }^{21}$ Samuel Mp. Hutabarat, 2008, Penawaran dan Penerimaan dalam Hukum Perjanjian, Grasindo, Jakarta, p. 70

${ }^{22}$ Oemar Mochtar, 2017, Dasar-Dasar Teknik Pembuatan Akta, Airlangga University, Surabaya, p. 52.

${ }^{23}$ Engga Prayoga dan RN Superteam, 2016, 233 Tanya Jawab Seputar Hukum Bisnis, Medpress Digital, Yogyakarta, p. 21.
} 
Based on this, the proficiency requirements contained in electronic contracts have the potential to be unfulfilled. This is because those who make electronic contracts through click warp have the potential to be immature, because they are under 18 years of age. Especially in the context of the use of smartphones or other devices related to the use of software applications, there are no clear rules regarding the minimum limits of users of such smartphones or devices. Furthermore, the existence of electronic contracts in software applications also has the potential to violate the provisions of Article 47 President Regulation No. 71 of 2019 on the Implementation of Electronic Systems and Transactions which states that electronic contracts contain at least one of the parties' identities. Implementation of electronic contracts in software applications generally use e-mail identity, but the use of this identity is also generally able to use anonymous email, so that the identity of the parties also can not be known correctly and with certainty.

Third, certain objects. An explanation of a particular matter can be substantially referred to through Articles 1331, 1332, and Article 1333 of the Civil Code. The substance of these articles provides guidance that in contracting, it must be clearly known about the object on which the agreement is based. This is intended so that the nature and extent of the obligations of the parties can be carried out, so that there is no uncertainty about the promised object. ${ }^{24}$ The object of the engagement is achievement, which must be fulfilled by the parties. In the case of certain objects, it is related to fulfilling the rights of the debtor and fulfilling the obligations of the creditor. ${ }^{25}$ In this regard, certain object requirements in electronic contracts in software applications have been fulfilled. This is because certain objects in the form of providing services from application providers have been listed in the electronic contract. In general, the contents of electronic contracts in software applications include messages/advertisements, application licenses, IPR violations, permission to use profits, and customer support.

Fourth, the object of the transaction must not be in conflict with the laws and regulations, decency, and public order. The discussion of the fourth condition relates to the contents of the agreement so that it does not conflict with statutory regulations, decency, and public order. Referring to this provision, the electronic contract in a software application has the potential to not fulfill the fourth condition. This is because electronic contracts generally use the internet network, so electronic contracts cover state boundaries and are generally written in foreign languages. The use of foreign languages in electronic contracts results in this contract being in conflict with Article 47 paragraph (1) President Regulation No. 71 of 2019 on the Implementation of Electronic Systems and Transactions which states that electronic contracts and other contractual forms as referred to in Article 46 paragraph (1) addressed to Indonesian citizens must be made in Indonesian. Similarly, Article 31 paragraph (1) of Act No. 24 of 2009 on Flags, Languages and Symbols of the State, as well as the National Anthem which states that Indonesian must be used in memoranda of understanding or agreements

\footnotetext{
${ }^{24}$ Agus Yudho Hernoko, Hukum Perjanjian; Asas Proporsionalitas dalam Kontrak Komersial, p. 191.

${ }^{25}$ Titik Triwulan Tutik, 2015, Hukum Perdata dalam Sistem Hukum Nasional, Cet. Kelima, Prenadamedia Group, Jakarta, p. 205.
} 
involving state institutions, government agencies of the Republic of Indonesia, Indonesian private institutions, or Indonesian citizens.

Based on the legal terms of the electronic contract, the electronic contract on the software application does not meet the legal requirements of the agreement, in the form of a skill and object of the transaction contrary to the laws and regulations. By not fulfilling the skill requirements, this contract violates the subjective conditions which consequently can be canceled by the court. While electronic contracts are against the laws and regulations, this contract violates objective conditions which means the contract is null and void. The consequence of an agreement that is null and void is that the agreement is considered never to occur and returned to its original condition, so that this electronic contract is considered to have never occurred. ${ }^{26}$

Based on this, by being canceled or nullified by law of electronic contracts in software applications, the act of accessing or retrieving data carried out by software application service providers for application users through electronic systems is contrary to Article 30 of the Act No. 19 of 2016 on Amendments to Act No. 11 of 2008 on Electronic Information and Transactions stating that every person intentionally and without rights or against the law accesses another person's computer and / or electronic system in any way convicted with a criminal sentence of no more than 6 (six) years and / or a fine of at least Rp. 600,000,000.00 (six hundred million rupiah).

\section{Closing}

Based on the results of such discussion, the electronic contract on a software application can be canceled and null and void by law. Electronic contracts in software applications can be canceled because they do not meet the subjective requirements in terms of skills. This is because those who make electronic contracts through click warp have the potential to be immature, because they are under 18 years of age. Especially in the context of the use of smartphones or other devices related to the use of software applications, there are no clear rules regarding the minimum limits of users of such smartphones or devices. President Regulation No. 71 of 2019 on the Implementation of Electronic Systems and Transactions.

\section{References}

[1] Agus Yudho Hernoko, 2014, Hukum Perjanjian; Asas Proporsionalitas dalam Kontrak Komersial, Cet. Keempat, Kencana, Depok.

[2] Burhan Bungin, 2018, Komunikasi Politik Pencitraan; The Social Construction of Public Administration (Scopa), Prenada Media Group, Jakarta.

[3] Edi Santoso, 2018, Pengaruh Era Globalisasi Terhadap Hukum Bisnis Di Indonesia, Kencana, Depok.

[4] Edy Santoso, 2015, Tinjauan Hukum Atas Click Warp Agreement Pada Kontrak Baku Elektronik Terkait Transaksi Elektronik, Jurnal Living Law, Vol. 7, No. 1.

\footnotetext{
${ }^{26}$ R. Soeroso, Perjanjian di Bawah Tangan Pedoman Praktis Pembuatan dan Aplikasi Hukum, p. 24.
} 
eISSN : 2581-2114, pISSN: 2406-9426

[5] Engga Prayoga dan RN Superteam, 2016, 233 Tanya Jawab Seputar Hukum Bisnis, Medpress Digital, Yogyakarta.

[6] H.M. Fauzan dan Baharudin Siagian, 2017, Kamus Hukum dan Yurisprudensi, Kencana, Depok.

[7] Marilang, 2017, Hukum Perikatan; Perikatan yang Lahir dari Perjanjian, Indonesia Prime, Makassar.

[8] Mustika Zed, 2008, Metodologi Penelitian Kepustakaan, Yayasan Obor Indonesia, Jakarta

[9] Oemar Mochtar, 2017, Dasar-Dasar Teknik Pembuatan Akta, Airlangga University, Surabaya.

[10] R. Soeroso, 2010, Perjanjian di Bawah Tangan; Pedoman Praktis Pembuatan dan Aplikasi Hukum, Penerbit Sinar Grafika.

[11] R. Subekti dan R. Tjitrosudibio, 2006, Kitab Undang-Undang Hukum Perdata (Burgerlijk Wetboek), Cet. Ke-37, Pradnya Paramita, Jakarta.

[12] Rustam Magun Pikahulan, 2019, Hukum Perikatan, IAIN Parepare Nusantara Press, Pare-Pare.

[13] Samuel Mp. Hutabarat, 2008, Penawaran dan Penerimaan dalam Hukum Perjanjian, Grasindo, Jakarta.

[14] Soerjono Soekanto dan Sri Mamudji, 2001, Penelitian Hukum Normatif (Suatu Tinjauan Singkat), Rajawali Pers, Jakarta.

[15] Sukami, 2008, Cyber Law: Kontrak Elektronik dalam Bayang-Bayang Pelaku Usaha, Pustaka Sutra, Surabaya.

[16] Susanti Adi Nugroho, 2015, Penyelesaian Sengketa Arbitrase dan Penerapan Hukumnya, Cet. Ketiga, Kencana,Depok.

[17] Suwardi, 2012, Hukum Dagang Suatu Pengantar, Penerbit Deepublish, Yogyakarta.

[18] Tim Redaksi BIP, 2017, UU No. 19 Tahun 2016 tentang Perubahan Atas UU No. 11 Tahun 2008 tentang Informasi dan Transaksi Elektronik, Penerbit Buana Ilmu Populer, Jakarta.

[19] Titik Triwulan Tutik, 2015, Hukum Perdata dalam Sistem Hukum Nasional, Cet. Kelima, Prenadamedia Group, Jakarta.

[20] https://en.m.wikipedia.org/wiki/Clickwrap.

[21] https://hukumadmissible.wordpress.com/tag/perjanjian. 